\title{
The Failings of Microfinance in India: Insights from a Randomized Evaluation of Spandana
}

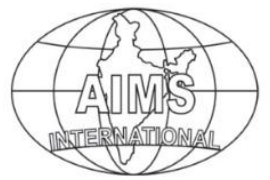

Volume 11, Number 1

January 2017, pp. 59-75

\author{
Vinti Agarwal \\ BBC Media Action, India \\ (drvinti@yahoo.co.in)
}

The microfinance industry in India, on a revival path after the crisis of 2010, is increasingly showing an urban focus. Micro-lending in urban areas has its limitations, more so with the model adopted by some of the for-profit microfinance institutions. A randomized evaluation of the lending operations of Spandana in an urban slum gives valuable insights of the contradictions inherent in a model that does not put entrepreneurship as its prime objective. Most important, it breaks apart the notion that blanket lending in the name of microfinance can reduce poverty, enhance livelihood opportunities, or even cause improvement in social indicators.

Keywords: Microfinance, India, Spandana, Randomized Evaluation

\section{Introduction}

The Indian microfinance sector passed through a serious crisis during the period 2010-2013 (Biswas 2010). The crisis originated in Andhra Pradesh which accounted for a more than a quarter of the then INR. 20,000 crore micro-lending industry, but soon affected operations of all microfinance institutions. It was a crisis waiting to happen, but the matters came to a head with a promulgation in October 2011 by the Andhra Pradesh state government regulating the microfinance industry in the wake of distress suicides following coercive recovery practices followed by some of the Micro Finance Institutions (State Government of Andhra Pradesh 2010). The loan recovery rate plummeted rate rapidly and many of the leading microfinance such as Trident Microfin Pvt. Ltd, Share Microfin Ltd, Asmitha Microfin Ltd., and Spandana Sphoorty Financial Ltd. were admitted to CDR. ${ }^{1}$ (Bandhyopadhyay and UnniKrishnan 2011)

Prior to the crisis, the micro finance industry had grown at a fairly rapid pace trying to capitalize on the expected potential of meeting the credit requirements of the populace at the bottom of the pyramid that was usually neglected by the formal banking system. In India, the financial inclusion model adopted was typically that of a frontend managed by a self -help group or a microfinance institution(MFI) with the bank providing the financing backend (Mahajan and Navin 2012). The earliest

\footnotetext{
${ }^{1}$ Corporate Debt Restructuring Mechanism is mechanism is a voluntary non-statutory system based on Debtor-Creditor Agreement (DCA) and Inter-Creditor Agreement (ICA) and the principle of approvals by super-majority of $75 \%$ creditors (by value) which makes it binding on the remaining $25 \%$ to fall in line with the majority decision. For more details, refer to ww.cdrindia.org
} 
introduction of the concept of microfinance emerged in the mid-1980s' with Myrada being set up in 1986 and Pradan in 1987 (Srivastava and Basu 2004). This was followed by the RBI approved SHG-Bank linkage program (SBLP) in 1986 which resulted in around 7.46 million SHGs linked to banks in March 2011 with total bank financing of 84 billion INR. in 2011-12 (Mahajan and Navin 2012).The SHG model had moderate success but was also used by certain states like Andhra Pradesh as a means of political patronage to attract a rural vote bank thorough the medium of heavily subsidized interest rates. Meanwhile, the success of the Grameen Bank in Bangladesh success invited replication in the form of privately managed commercial MFIs. Some began as non-profit institutions, but soon transitioned to a for profit model using the legal structure of a non-banking finance company to attract equity investments from microfinance investment vehicles and private equity funds (CGAP 2010). These include SKS Spandana, SHARE and Asmitha all of which operated in Andhra Pradesh. Increasing access to equity funding led to even more pressure to make profits for some of the MFI's, a case in example of SKS decision to make a public issue (MIX Market 2010) (Chen, et al. 2010).In a bid to replicate the success of SKS, Spandana Sphoorty, too had finalized plans to go public in 2011 (Moneycontrol.com 2010).

Though the October 2011 promulgation was the immediate factor in the downslide of the industry, the practices of the industry had already invited a serious question mark on its motivations and functioning. The high emphasis on portfolio sizes, return on equity and reduction in operating costs, seemed to work against reaching out to the poorest section or providing the necessary education and disclosure about interest rates and repayment requirements. Instead of a primary objective of building entrepreneurship, it only seemed to replace the money lender in terms of lending for consumption purposes. Most important, it increased indebtedness manifold especially in the state of Andhra Pradesh.

\subsection{Growth of Microfinance in India through the Prism of Andhra Pradesh}

Much of the developments in the microfinance industry and subsequent regulation owe its origin to the nature of the microfinance movement in Andhra Pradesh, where growth practices were not completely facilitative of using the microfinance intervention as a social transformational tool. Andhra Pradesh was characterized by the simultaneous expansion of SHG Bank Linkage Model promoted by the State, and the MFI model by private players. Eventually the MFI industry overtook the SHG sector in loan outstanding terms, but not without increasing the average indebtedness of households in Andhra Pradesh (Srinivasan 2010). Interest rates were as high as $31-32 \%$ and there was huge competition for clients (Mader 2013). In a survey conducted by Institute of Financial Management Research, it was found that though only $11 \%$ of the borrowing was from an MFI, while $84 \%$ of the rural households had multiple loans outstanding (Johnson and Meka 2010). As per the Microfinance State of the Sector 2011 report, Andhra Pradesh had the highest concentration of microfinance operations with 17.31 million SHG members and 6.24 million MFI clients. The total loans across both SHG and Microfinance stood at INR. 1,57,692/million with average loan outstanding per poor household at INR. 62,527/- compared to a national average of INR. 7,700/- (Ghiyazuddin and Gupta 2012). The unhealthy practices of the MFI industry in Andhra Pradesh led to regulatory intervention by the Reserve Bank of India, the regulator for the financial and banking sector in India. 
The interest margin was capped within a range of $10-12 \%$, the quantum of loans given in the first and second waves restricted as per income status, and caps fixed on proportion of loan given for consumption purposes. Limits were also placed on the total number of lending agencies from which a household can borrow from (Malegam 2011).

\subsection{Recent Developments in the Microfinance Industry}

Recently the industry is showing signs of revival. As per a Karvy stock broking report, the industry recorded a 55\% growth in new loan disbursement and a $61 \%$ growth in gross loan portfolio in the financial year of 2014-2015 (PTI 2015). As per MFIN estimates in 2016, the microfinance industry is now dominated by the NBFC MFI with an $88 \%$ market share. Although there were approximately 56 MFI's operating in the country, 22 of them individually had a loan portfolio of greater than 5 billion INR and accounted for $90 \%$ of the gross loan portfolio of the MFI industry. The share of the urban gross loan portfolio was $40 \%$, and $64 \%$ of the loan was given for non-agricultural purposes (Ernst and Young 2016) (MFIN 2016). While the news of the revival is to be welcomed, what is striking is the increasing urban focus of the microfinance industry. The share of rural customers has gone down to only $33 \%$ in 2015 from a high of $69 \%$ in 2012 . There has been also a rise in certain completely urban focused MFIs such as Janalakshmi Financial Services Pvt. Ltd, Ujjivan Financial Services Pvt. Ltd and Satin Credit Card Network Ltd (Bandyopadhyay 2015). Given this development, it becomes important to study the impact of microfinance in a relatively urban setting. The randomized evaluation of microfinance in an urban slum of Hyderabad during the period 2005-2008 using the operations of Spandana is a good case example. Results from the evaluation clearly illustrate the limitations of using microfinance intervention to foster entrepreneurship outcomes even in urban settings. These results are broadly in line with other random evaluation studies carried out. Subsequent regulatory modifications may serve to control the excesses of the industry, but do not materially alter the outcomes of the intervention with the given microfinance models in vogue.

\section{Learnings from Other Randomized Evaluation Studies}

Several randomized evaluation studies in the countries of Morocco, BosniaHerzegovina, Mexico, Mongolia, India and Ethopia have been conducted with widely differing results. Despite the challenges of conducting a random evaluation, studies have reported some positive impact on business activity and income composition but very mixed results on household consumption or income. Results on female empowerment and education too have been mixed (Bannerjee, et al. 2015).

In Mongolia, 1148 women across 40 villages were assigned to three different cohorts with access to group loans, individual loans or no loans respectively. Results shows that though loans were provided to finance business creation, almost half of it went for household consumption. Statistical significant results of increase in the likelihood of owning an enterprise by $9 \%$ was witnessed only amongst women who were offered group loans. Other findings for the group loan cohort included an increase in hours worked by women by 6 hours per week, positive impacts on food consumption and on business assets, but not on household assets or current income. These effects did not show up on the cohort of women accessing individual loans although repayment rates were roughly similar. However, repeat borrowing by 
individual borrowers was substantially less than that of group borrowers (Orazio, et al. 2015). The randomized evaluation of the microfinance intervention carried out in the urban slums of Hyderabad at the end of 15 months showed that there was no effect of access to microcredit on average monthly expenditure per capita but impacts on durable expenditure effect were heterogeneous. There also seemed to be no significant impact on health, education or women's decision making although there was some impact on creation of new businesses and a decline in wasteful expenditure (Bannerjee, Duflo, et al. 2009).

Results on a microcredit evaluation in rural Morocco found a very low uptake of $13 \%$ for microfinance loans. Among households identified as more likely to borrow, microcredit access led to a significant rise in investment in assets used for selfemployment activities, an increase in profit, and a reduction in income from casual labor. The effects were however quite heterogeneous (Crepon, et al. 2015). A similar study in Salem in Tamil Nadu reported target households registering $11.41 \%$ higher annual average income as compared to the control group but not very significant results on other parameters (Chandrakumarmangalam and Vetrivel 2012).

A study in 2003 in Bangladesh found that a 10-percent increase in female borrowing increases household per capita total expenditure by 0.2 percent, food expenditure by 0.1 percent, non-food expenditure by 0.5 percent and household nonland asset by 0.2 percent though no positive effects were seen in men (Khandker 2005). In a replication study using propensity matching, results indicated both negative as well as positive often statistically insignificant, average microcredit impacts. Women were also ruled out has having an obvious advantage over men (Duvendack and Palmer-Jones 2012). Analysis of other evaluation studies too have identified low take off rates for microfinance, and therefore low returns as well. Results for increased entrepreneurship are varied, but there may be some outcomes of increased consumption and investment in durable goods, increase in ability to withstand adverse shocks and some improvement in social indicators such as education for children (Bauchet, et al. 2011).

\section{Data and Methods}

The data is taken from a randomized evaluation of the effect of the canonical grouplending microcredit model initiated in 2005 that targets women who may not necessarily be entrepreneurs. It consists of two end-line surveys carried out after 1518 months and 3.5 years respectively after initiation. ${ }^{2} 52$ out of 104 poor neighborhoods in Hyderabad were randomly selected for the opening of a Spandana branch. A comprehensive household survey was conducted with an average of 65 households in each neighborhood, for a total of about 6,850 households for both Endline surveys. By the end of the second survey, both Spandana and other organizations had started lending in the treatment and control groups, so the fraction of households borrowing from microcredit organizations was not dramatically different (35 percent in treatment and 33 percent in control). This second survey thus gives an opportunity to examine some of the longer-term impacts of microcredit access on households and businesses, who borrow and those who do not borrow at all. The joint lending groups were formed by women themselves and were free to

${ }^{2}$ Called Endline I and Endline II respectively and was conducted by IFMR and J-PAL 
choose the best use of the loan. They were also not exposed to any entrepreneurship or financial literacy training. Though a baseline survey was conducted with 2800 observations, it was used only to identify the treatment and control groups and uptake of micro-credit and therefore no analysis in terms of the comparison between the baseline and end-line results can be taken up. As results show in Table 1, the baseline survey could ensure broad equivalence between control and treatment groups which the study achieved. However as evident from results given in Table 2, the variables of total outstanding debt in area, total number of businesses in area, area mean monthly per-capita expenditure, and area literacy rate ( $\mathrm{HH}$ heads only) were significantly different across the groups. Consequently, these variables were used as control variables.

Table 1 Background Characteristics of Control and Treatment Group as per Baseline Survey

\begin{tabular}{|l|c|c|c|c|}
\hline & Control & Treatment & Difference & $\begin{array}{c}(p- \\
\text { value }\end{array}$ \\
\hline Household size & 5.04 & 5.13 & -0.10 & 0.17 \\
\hline Adults (16 and older) in household & 3.44 & 3.43 & 0.01 & 0.85 \\
\hline Children (15 and younger) in household & 1.60 & 1.70 & -0.10 & 0.04 \\
\hline Male head of household & 0.91 & 0.89 & 0.01 & 0.31 \\
\hline Age of head of household & 41.15 & 40.91 & 0.24 & 0.58 \\
\hline Head of household with no education & 0.37 & 0.36 & 0.01 & 0.69 \\
\hline Has outstanding loan from Spandana & 0.00 & 0.01 & -0.01 & 0.00 \\
\hline Has outstanding loan from non-Spandana MFI & 0.01 & 0.02 & -0.01 & 0.17 \\
\hline Has outstanding loan from bank & 0.04 & 0.04 & -0.00 & 0.85 \\
\hline Has outstanding informal loan & 0.63 & 0.63 & -0.00 & 0.94 \\
\hline Has any outstanding loan & 0.68 & 0.68 & -0.00 & 0.91 \\
\hline Total outstanding loan amount, Spandana (INR.) & 0.00 & 68.97 & -68.97 & 0.02 \\
\hline Total outstanding loan amount, non-Spandana MFI & 201.15 & 371.51 & -170.36 & 0.38 \\
\hline (INR.) & $7,438.17$ & $2,018.47$ & $5,419.70$ & 0.28 \\
\hline Total outstanding loan amount, banks (INR.) & $28,460.02$ & $27,889.56$ & 570.46 & 0.83 \\
\hline Total outstanding loan amount, informal (INR.) & $37,892.00$ & $32,013.45$ & $5,878.56$ & 0.32 \\
\hline Total outstanding loan amount (INR.) & 0.32 & 0.30 & 0.02 & 0.48 \\
\hline Number of household businesses & 0.15 & 0.14 & 0.01 & 0.68 \\
\hline Number of female-run businesses & 0.49 & 0.48 & 0.01 & 0.89 \\
\hline Percent of businesses managed by women & $15,990.64$ & $20,491.87$ & $-4,501.23$ & 0.34 \\
\hline Business sales per month (INR.) & $3,617.42$ & $4,257.97$ & -640.55 & 0.73 \\
\hline Business expenses per month (INR.) & 384.71 & 399.19 & -14.48 & 0.95 \\
\hline Business investment per month (INR.) & 0.17 & 0.42 & -0.25 & 0.09 \\
\hline Employees in all businesses & 15.32 & 71.73 & 4.59 & 0.35 \\
\hline $\begin{array}{l}\text { Total hours/week worked in self-employment by } \\
\text { household members }\end{array}$ & 1.94 & 1.97 & -0.03 & 0.43 \\
\hline Total expenditure per month (INR.) & $5,158.11$ & -269.68 & 0.13 \\
\hline Non-durables expenditure per month (INR.) & $4,986.50$ & -251.82 & 0.13 \\
\hline Durables expenditure per month (INR.) & 171.61 & -17.86 & 0.44 \\
\hline Household (non-business) durable good index & & \\
\hline & & & \\
\hline
\end{tabular}


Table 2 Test of Differences between Control and Treatment Groups for Control Variables as per Baseline

\begin{tabular}{|l|c|c|c|c|c|c|}
\hline & $\begin{array}{c}\text { Control } \\
\text { (Mean) }\end{array}$ & $\begin{array}{c}\text { Control } \\
\text { (SD) }\end{array}$ & $\begin{array}{c}\text { Treatment } \\
\text { (Mean) }\end{array}$ & $\begin{array}{c}\text { Treatment } \\
\text { (SD) }\end{array}$ & Difference & $\begin{array}{c}p \text { - } \\
\text { value }\end{array}$ \\
\hline $\begin{array}{l}\text { No. of businesses opened } \\
\text { 1 year or more before } \\
\text { End-line 1 }\end{array}$ & 0.38 & 0.67 & 0.39 & 0.65 & -0.01 & 0.65 \\
\hline $\begin{array}{l}\text { Had business for year or } \\
\text { more before End-line 1 }\end{array}$ & 0.31 & 0.46 & 0.31 & 0.46 & -0.01 & 0.55 \\
\hline $\begin{array}{l}\text { Total outstanding debt in } \\
\text { area, baseline }\end{array}$ & 36487.45 & 35183.95 & 31653.01 & 17061.58 & 4834.44 & 0.00 \\
\hline $\begin{array}{l}\text { Total number of } \\
\text { businesses in area, } \\
\text { baseline }\end{array}$ & 7.45 & 5.01 & 6.78 & 4.76 & 0.67 & 0.00 \\
\hline $\begin{array}{l}\text { Area mean monthly per- } \\
\text { capita expenditure, } \\
\text { baseline }\end{array}$ & 981.32 & 163.19 & 1002.96 & 184.00 & -21.65 & 0.00 \\
\hline $\begin{array}{l}\text { Area literacy rate (HH } \\
\text { heads only), baseline }\end{array}$ & 0.61 & 0.16 & 0.62 & 0.12 & -0.01 & 0.00 \\
\hline $\begin{array}{l}\text { Area literacy rate, } \\
\text { baseline }\end{array}$ & 0.68 & 0.09 & 0.68 & 0.07 & 0.00 & 0.43 \\
\hline
\end{tabular}

Though there was some attrition across the number of people surveyed in Endline I (6863) vis-à-vis Endline II (6142), a test of differences of means with respect to background variables such as household size, adult equivalent household size, adults, children, proportion of households having male head, age of head of household, proportion of household head with no education, proportion of women in the age category of 18-45, proportion of children in age category of 13-18 showed no significant differences across both Endlines. This indicated that that attrition was roughly equal across both control and treatment groups and the selection effect was negligible in across control and treatment group. Therefore, treatment estimates could be regarded as unbiased. As per the results given in Table 3, there was a significant difference in the exposure of Spandana between control and treatment areas at $1 \%$ significance level at both Endlines. This enables the measurement of the incremental impact of Spandana in treatment areas vis-à-vis control areas. However, the incremental impact might be different for different households which is not possible to be measured in this study.

\section{Model Construction}

The primary construction of the equation would take the form of

$\mathrm{Y}_{\mathrm{ia}}=\alpha+\beta \times$ Treatment $_{\mathrm{ia}}+\mathrm{X}_{\mathrm{a} \gamma}^{\prime}+\varepsilon_{\mathrm{ia}}$,

Where $\mathrm{Y}_{\mathrm{ia}}$ is an outcome for household $\mathrm{i}$ in area a, Treatment ${ }_{\mathrm{ia}}$ is an indicator for living in a treated area, and $\beta$ is the intent-to-treat effect. $X^{\prime}$ a is a vector of control variables, which measures for the baseline, variables of, had business for a year before Endline I, area outstanding debt, total number of businesses in area, area population, area mean monthly per-capita expenditure, area literacy rate (Household heads only). Standard errors are adjusted for clustering at the area level. 
Certain limitations are always inherent in the conduct of any randomized study. Since the take up credit rates consisted of only $25 \%$ of households, confidence intervals of estimates are bound to be much larger. There will also be a great deal of heterogeneity in the impacts on different households. Impacts may be substantially different on the borrowers and/or communities already being served before the lenders in these studies began experimenting on the margin though the effect has been somewhat adjusted using control variables at the baseline. There is bound to be some selection effects, given borrowers would tend to self-select, and lenders may choose to eliminate riskier borrowers. The heterogeneity in loan purpose uses makes it difficult to detect separate household effects, since some households use loans to grow businesses, some for consumption smoothing and some for empowerment.

Table 3 Test of Differences across Different Lenders for Control and Treatment Groups for Endline I \& Endline II

\begin{tabular}{|c|c|c|c|c|c|c|c|c|}
\hline Variable & $\begin{array}{l}\text { Control } \\
\text { (Mean) }\end{array}$ & $\begin{array}{c}\text { Treatment } \\
\text { (Mean) }\end{array}$ & Difference & p-value & $\begin{array}{l}\text { Control } \\
\text { (Mean) }\end{array}$ & $\begin{array}{l}\text { Treatment } \\
\text { (Mean) }\end{array}$ & Difference & e p-value \\
\hline \multicolumn{9}{|c|}{ By Mean Proportion } \\
\hline & \multicolumn{4}{|c|}{ Endline I } & \multicolumn{4}{|c|}{ Endline II } \\
\hline Spandana & 0.05 & 0.21 & -0.16 & $0.000 * * *$ & 0.11 & 0.19 & -0.08 & $0.000 * * *$ \\
\hline Other MFI & 0.15 & 0.14 & 0.01 & 0.156 & 0.27 & 0.24 & 0.03 & 0.009 ** \\
\hline Any MFI & 0.18 & 0.29 & -0.10 & $0.000 *$ & 0.33 & 0.35 & -0.02 & 0.114 \\
\hline Any Bank & 0.08 & 0.08 & 0.00 & 0.475 & 0.07 & 0.07 & 0.00 & 0.841 \\
\hline $\begin{array}{c}\text { Any } \\
\text { Informal }\end{array}$ & 0.76 & 0.71 & 0.05 & $0.000 * * *$ & 0.60 & 0.60 & 0.00 & 0.970 \\
\hline Any Loan & 0.87 & 0.85 & 0.02 & $0.028 * *$ & 0.90 & 0.91 & 0.00 & 0.785 \\
\hline \multicolumn{9}{|c|}{ By Amount } \\
\hline Spandana & 597.44 & 2229.97 & -1632.53 & $0.000 * * *$ & 1566.64 & 2766.51 & -1199.87 & $0.000 * *$ \\
\hline Other MFI & 1806.03 & 1701.31 & 104.72 & 0.442 & 4775.06 & 4699.87 & 75.18 & 0.799 \\
\hline Any MFI & 2373.78 & 3960.72 & -1586.94 & $0.000 * * *$ & 5544.16 & 6681.41 & -1137.24 & $0.000 * *$ \\
\hline Any Bank & 8422.43 & 9058.64 & -636.21 & 0.752 & 6126.52 & 5276.68 & 849.84 & 0.351 \\
\hline \begin{tabular}{|c|} 
Any \\
Informal
\end{tabular} & 41044.62 & 40434.50 & 610.13 & 0.772 & 32355.99 & 32541.55 & -185.56 & 0.928 \\
\hline Any Loan & 59836.27 & 64082.52 & -4246.25 & 0.311 & 88631.46 & 93040.28 & -4408.82 & 0.250 \\
\hline
\end{tabular}

\section{Results}

As per the baseline survey, the area selected for microfinance intervention had an extremely low presence of formal institutions although informal sources of borrowing were fairly high. Overall $68.62 \%$ of the households had some level of debt with an average amount of loan of INR 34,947/- across both areas with the nonformal sector accounting for $63.3 \%$ of the households and an average loan of INR $28,174 /$ - . Only $24 \%$ of the households were running businesses of which 48.5 percent were managed by women. The impact of treatment on different outcomes was calculated with and without controls. The general direction of results has been the same, but using controls have affected absolute value of coefficients and significance levels. Barring the variable of had old business, all other covariates were based on area levels. Since, the objective of the study was intended to study outcomes as a result of the microfinance intervention, all estimates of results presented have used control covariates. It appears that the factor of having businesses earlier has been generally significant across most of the money metric measures that 
is indebtedness, income, wages, expenditure, business profits and investment. Table 4 in fact shows that there is sizeable difference in borrowing amounts between households that had businesses earlier vis-à-vis those who did not. The rest of the control factors do not seem to have a very significant impact except education in certain select cases and hence estimates not displayed.

Table 4 Difference in Borrowing Amounts if there was an Old Business

\begin{tabular}{|l|c|c|c|c|c|c|c|c|}
\hline & \multicolumn{4}{|c|}{ Endline I } & \multicolumn{4}{c|}{ Endline II } \\
\hline & \multicolumn{2}{|c|}{$\begin{array}{c}\text { Had Old } \\
\text { Business }\end{array}$} & \multicolumn{2}{c|}{$\begin{array}{c}\text { Did not Have old } \\
\text { business }\end{array}$} & \multicolumn{2}{c|}{$\begin{array}{c}\text { Had Old } \\
\text { Business }\end{array}$} & \multicolumn{2}{c|}{$\begin{array}{c}\text { Did not Have old } \\
\text { business }\end{array}$} \\
\hline & Obs. & Mean & Obs. & Mean & Obs. & Mean & Obs. & Mean \\
\hline Spandana & 2,074 & 2302.84 & 4,614 & 1072.40 & 1,878 & 3060.87 & 4,159 & 1786.49 \\
\hline Other MFI & 2,050 & 2578.41 & 4,538 & 1378.36 & 1,878 & 5900.93 & 4,159 & 4158.92 \\
\hline Any MFI & 2,074 & 4841.71 & 4,614 & 2472.46 & 1,878 & 7976.22 & 4,159 & 5250.78 \\
\hline $\begin{array}{l}\text { Bank } \\
\text { Amount }\end{array}$ & 2,074 & 14027.43 & 4,614 & 6412.86 & 1,878 & 6041.45 & 4,159 & 5551.37 \\
\hline $\begin{array}{l}\text { Informal } \\
\text { Loan }\end{array}$ & 2,074 & 49709.87 & 4,614 & 36464.85 & 1,878 & 35971.45 & 4,159 & 30658.94 \\
\hline Any Loan & 2,088 & 85845.64 & 4,650 & 50946.73 & 1,878 & 107210.70 & 4,159 & 83036.42 \\
\hline
\end{tabular}

The results for all outcomes are presented from Table 5 to Table 12. Estimates of treatment in Table 5 for loan proportion from various financial institutions suggest that that treatment effect was positive for Spandana at both Endlines although by the time of the second Endline, the incremental impact had come down from $16 \%$ to $8 \%$. It was also found that a significant $6 \%$ of the borrowers who were given a loan tended not to default at Endline I but the default percentage increased to an insignificant $1 \%$ at Endline II. The average number of loan cycles however increased to .13 at Endline II from .11 at Endline I, both estimates being significant. The entry of MFI's had also reduced borrowing from informal loans at the first Endline but thereafter had no further decline leading to an overall constant proportion of 0.73 .

Table 5 Loan Proportion

\begin{tabular}{|c|c|c|c|c|c|c|c|c|}
\hline & \multicolumn{8}{|c|}{ Endline I } \\
\hline & Spandana & $\begin{array}{l}\text { Other } \\
\text { MFI }\end{array}$ & $\begin{array}{l}\text { Any } \\
\text { MFI }\end{array}$ & $\begin{array}{l}\text { Any } \\
\text { Bank }\end{array}$ & $\begin{array}{c}\text { Any } \\
\text { Informal }\end{array}$ & $\begin{array}{l}\text { Any } \\
\text { Loan }\end{array}$ & $\begin{array}{l}\text { Ever } \\
\text { Late }\end{array}$ & $\begin{array}{l}\text { Loan } \\
\text { Cycles }\end{array}$ \\
\hline Treatment & $0.16 * * *$ & -0.00 & $0.11 * * *$ & 0.00 & $-0.05 * *$ & -0.02 & $-0.06 * *$ & $0.11 * *$ \\
\hline $\begin{array}{l}\text { Any Old } \\
\text { Business }\end{array}$ & $0.09 * * *$ & $0.08 * * *$ & $0.14 * * *$ & $0.04 * * *$ & -0.01 & $0.04 * * *$ & 0.02 & $0.21 * * *$ \\
\hline $\begin{array}{l}\text { Literacy } \\
(\mathrm{HH})\end{array}$ & -0.02 & -0.05 & -0.09 & $0.06^{*}$ & $-0.14 * *$ & $\begin{array}{c}- \\
0.11^{* * * *}\end{array}$ & $\begin{array}{c}- \\
0.30^{* * * *}\end{array}$ & -0.08 \\
\hline \multirow[t]{2}{*}{ Constant } & 0.06 & $0.20 * *$ & $0.23^{* *}$ & 0.03 & $0.97 * * *$ & $1.00 * * *$ & $0.91 * * *$ & $0.30 *$ \\
\hline & \multicolumn{8}{|c|}{ Endline II } \\
\hline Treatment & $0.08^{* * *}$ & -0.03 & 0.02 & -0.00 & 0.00 & 0.00 & 0.01 & $0.13 *$ \\
\hline $\begin{array}{l}\text { Any Old } \\
\text { Business }\end{array}$ & $0.08 * * *$ & $0.06 * * *$ & $0.10 * * *$ & 0.02 & -0.01 & 0.01 & -0.01 & $0.31 * * *$ \\
\hline $\begin{array}{l}\text { Literacy } \\
(\mathrm{HH})\end{array}$ & -0.01 & $-0.20^{* *}$ & $-019^{*}$ & 0.02 & $-0.14^{* *}$ & $\begin{array}{c}- \\
0.14^{* * * *}\end{array}$ & $-0.16^{*}$ & -0.35 \\
\hline Constant & $0.19 * *$ & $0.46^{* * *}$ & $0.55^{* * *}$ & $0.10^{* *}$ & $0.73 * * *$ & $1.02 * * *$ & $0.84 * * *$ & $0.90 * * *$ \\
\hline
\end{tabular}

$* 5 \%$ level of significance; ** $1 \%$ level of significance; $* * * .01 \%$ level of significance

Note: All figures are in proportion 
Table 6 gives estimates for indebtedness and clearly shows that the treatment effect for average loan amount borrowed from Spandana was significant at both Endline I and Endline II with incremental increase of INR. 1681/- and INR. 1232/respectively. The impact across the other types of borrowing was not significant though the direction of the coefficients did indicate incremental borrowing for informal sources and banks had declined at the end of the first Endline, but picked up for informal sources at Endline II. The highly significant constant of INR. 75,969/- at $1 \%$ significance level at the end of Endline II may be taken as evidence of high incidence of indebtedness in both control and treatment areas. The coefficients of old business were generally significant across all forms of borrowing at both Endlines except bank borrowing at Endline II. Looking at results for both Tables, it indicates banks being edged out in favor of microfinance institutions and informal sources remaining a preferred choice in the long run in terms of total borrowing but slight reduction in average proportion. A higher education predisposes borrowing from the bank against informal sources. The high significant constant coefficients for both proportions and amounts indicate a higher level of base borrowing across both the control and treatment areas. Lower insignificant treatment coefficients for proportion of loan and absolute amount borrowed for Endline II do seem to indicate an avoidance of further borrowing in the wake of already existing high amounts of debt accumulated.

Table 6 Loan Amount

\begin{tabular}{|l|c|c|c|c|c|c|}
\hline & \multicolumn{6}{|c|}{ Endline I } \\
\hline & Spandana & Other MFI & Any MFI & Bank & $\begin{array}{c}\text { Informal } \\
\text { Loan }\end{array}$ & Any Loan \\
\hline Treatment & $1,681.35^{* * *}$ & -17.45 & $1,720.55^{* * *}$ & -223.77 & -869.74 & $3,302.48$ \\
\hline $\begin{array}{l}\text { Old } \\
\text { Business }\end{array}$ & $1,197.94 * * *$ & $1,216.06 * * *$ & $2,355.41^{* * * *}$ & $7,710.58 * * *$ & $13,141.98^{* * * *}$ & $34,836.01 * * *$ \\
\hline $\begin{array}{l}\text { Literacy } \\
\text { (HH) }\end{array}$ & -219.88 & -635.76 & -390.43 & $10,664.30^{*}$ & $-8,573.75$ & -20.32 \\
\hline Constant & 100.09 & $2,468.61 * *$ & $2,168.24$ & $-6,703.83$ & $24,512.11^{* *}$ & $19,046.18$ \\
\hline & \multicolumn{7}{|c|}{ Endline II } \\
\hline Treatment & $1,231.73^{* * *}$ & -38.26 & $1,199.86$ & $-1,362.62$ & 550.46 & $3,828.15$ \\
\hline $\begin{array}{l}\text { Old } \\
\text { Business }\end{array}$ & $1,256.64 * * *$ & $1,736.32 * * *$ & $2,702.96 * * *$ & 698.88 & $5,123.86 * *$ & $24,552.85 * * *$ \\
\hline $\begin{array}{l}\text { Literacy } \\
\text { (HH) }\end{array}$ & 66.63 & $-2,446.58$ & $-1,971.32$ & $11,027.06 * *$ & $-11,964.59$ & 416.55 \\
\hline Constant & $2,862.20^{* *}$ & $8,194.65 * * *$ & $9,688.17 * * *$ & $-3,034.80$ & $27,082.39 * *$ & $75,968.85^{* * *}$ \\
\hline
\end{tabular}

$* 5 \%$ level of significance; ** $1 \%$ level of significance; ***.01\% level of significance

Note: All figures are in INR

The incremental impact of microfinance intervention on business outcomes is shown in Table 7. For most of the outcomes, estimates were insignificant except Investment at Endline I and Assets at Endline II. The business investment increased by a significant INR. 366/- in treatment areas over last 12 months at Endline I but declined to an insignificant INR. -156/- at Endline II. There was however an incremental increase in stock of Business Assets by INR. 1,172/- in treatment areas at Endline II. Since the control variable of having existing businesses was extremely 
significant across all outcomes, though the coefficients had declined by the end of Endline II, it indicated that the business outcomes might have been positive only for those who had existing businesses. Those not having existing business did not seem to benefit from the microfinance intervention except in terms of increase in assets.

Table 7 Business Outcomes

\begin{tabular}{|c|c|c|c|c|c|c|}
\hline & \multicolumn{7}{|c|}{ Endline I } \\
\hline & Assets & Investment & Revenue & Expense & Profits & Employees \\
\hline Treatment & 520.63 & $366.09 *$ & 801.32 & 83.63 & 364.54 & -0.02 \\
\hline Old Business & $6,639.77 * * *$ & $1,075.93 * * *$ & $15,442.09 * * *$ & $12,407.87 * * * 3,025.25 * * *$ & $0.39 * * *$ \\
\hline Literacy (HH) & $2,347.51 *$ & -108.76 & $-1,099.86$ & $-1,969.62$ & $-1,121.26$ & 0.05 \\
\hline Constant & $-1,504.08$ & -149.62 & $-9,064.71 * *$ & $-6,469.27 * *$ & -160.71 & -0.17 \\
\hline & \multicolumn{7}{|c|}{ Endline II } \\
\hline Treatment & $1,172.08 * *$ & -155.96 & 151.73 & -721.66 & 555.78 & -0.03 \\
\hline Old Business & $8,137.83 * * *$ & $1,338.24 * * *$ & $9,673.92 * * *$ & $8,807.34 * * *$ & $1,751.56 * * *$ & $0.26 * * *$ \\
\hline Literacy (HH) & 205.02 & $-1,265.35$ & $-2,188.87$ & $-2,000.37$ & 340.34 & 0.19 \\
\hline Constant & $2,440.49$ & $1,436.48 *$ & 816.28 & $2,035.75$ & -425.26 & -0.01 \\
\hline
\end{tabular}

$* 5 \%$ level of Significance; ** 1\% Level of Significance; ***.01\% Level of Significance

Note: All figures are in INR

As evident from Table 8, the entrepreneurship outcomes generally lasted only through Endline I and generally petered down by Endline II. There was only a positive increment of .02 in number of new businesses among women amongst those who did not own businesses earlier at Endline I. By Endline II, there was no increase in new business, but possibly among those who had started one, there was a .05 increase in total number of businesses. Those who had existing businesses scaled up the existing ones by Endline I but showed a decline by Endline II. There was an insignificant decline in wages which implied that entrepreneurship did not replace wages. The decline in wages was far more significant for those who had existing businesses. All in all, results suggest that there was hardly any new increment in entrepreneurial activity and even those who had existing businesses showed a decline by Endline II.

Table 8 Entrepreneurship

\begin{tabular}{|c|c|c|c|c|c|c|}
\hline VARIABLES & $\begin{array}{c}\text { Any } \\
\text { Business }\end{array}$ & \begin{tabular}{|c|} 
Total \\
Business
\end{tabular} & \begin{tabular}{|c|} 
New \\
Business
\end{tabular} & \begin{tabular}{|c|} 
Female \\
Businesses
\end{tabular} & $\begin{array}{c}\text { Female } \\
\text { Business New }\end{array}$ & $\begin{array}{c}\text { Wages } \\
\text { Non Business }\end{array}$ \\
\hline & \multicolumn{6}{|c|}{ Endline I } \\
\hline Treatment & 0.01 & 0.01 & $0.02 * *$ & 0.01 & $0.02 * * *$ & -510.26 \\
\hline Old Business & $0.94 * * *$ & $1.41 * * *$ & 0.00 & $0.53^{* * *}$ & 0.01 & $-1,660.62 * * *$ \\
\hline Literacy $(\mathrm{HH})$ & -0.01 & -0.05 & 0.03 & 0.00 & $0.03 *$ & $1,502.73$ \\
\hline \multirow[t]{2}{*}{ Constant } & $0.04 * *$ & 0.11 & 0.04 & -0.00 & 0.00 & $2,005.79 *$ \\
\hline & \multicolumn{6}{|c|}{ Endline II } \\
\hline Treatment & 0.02 & $0.05 *$ & 0.01 & -0.01 & -0.00 & -138.99 \\
\hline Old Business & $0.58 * * *$ & $0.86^{* * *} *$ & $0.07 * * *$ & $0.33^{* * *}$ & $0.02^{* * *}$ & $-1,944.22 * * *$ \\
\hline Literacy $(\mathrm{HH})$ & -0.03 & -0.04 & -0.06 & -0.00 & -0.02 & $1,348.86^{*}$ \\
\hline Constant & $0.34 * * *$ & $0.52 * * *$ & $0.15 * * *$ & $0.15^{* *}$ & $0.07 * *$ & $3,843.35 * * *$ \\
\hline
\end{tabular}

$* 5 \%$ Level of Significance; ** 1\% Level of Significance; ***.01\% Level of Significance

Note: Except for Wages, all other Variables are Given in Number of Businesses 
Table 9 shows the incremental effect of treatment on number of hours worked per week. There was a significant but low overall 2.25 additional hours per week at Endline I taking into account all family members for those who did not have an existing business. Since the hours of work for self-employment (SE) was not significant for spouse/ head of family nor for children, it may have only resulted in some extra hours for the female member but not for the spouse or head of household. This incremental impact however did not last till Endline II. The high significant coefficients for Old Business for both Endlines does indicate that female members reduced outside employment with preference for working for own business. This too seemed to show a decline by Endline II. In fact, by Endline II, the total number of hours for the entire family seemed to suggest a constant 90 hour week against 80 hours at Endline I, with some increase of 9 hours per week in case there was an existing business. Child labor may have reduced slightly in families where the head of the family was literate, more so for boys, although there was a decline of 2 hours per week work at $10 \%$ significance level for the female child only at Endline I. Overall it might have replaced hours worked outside for self-employment for the women, but impacts did not particularly percolate to the rest of the family.

Table 9 Hours of Work over the Last 7 Days

\begin{tabular}{|c|c|c|c|c|c|c|c|c|c|}
\hline & \multicolumn{3}{|c|}{ For all Members of Family } & \multicolumn{3}{|c|}{ For Spouse/Head of Family } & \multicolumn{3}{|c|}{ Children 16-20 Years } \\
\hline & Total & SE & Out & Total & SE & Out & Both & Girl & Boy \\
\hline \multicolumn{10}{|c|}{ Endline I } \\
\hline Treatment & 0.72 & $2.25 *$ & -1.61 & $3.24 * *$ & 0.39 & $2.84 * *$ & -1.57 & $-2.04 *$ & 0.10 \\
\hline Old Business & $15.04 * * *$ & $97.86^{* * * *}$ & $-82.72 * * *$ & $12.26 * * *$ & $-22.31 * * *$ & $34.57 * * *$ & 1.03 & -0.33 & 0.91 \\
\hline Literacy $(\mathrm{HH})$ & -5.81 & 2.64 & -8.07 & -4.38 & -1.47 & -2.92 & -2.94 & -4.25 & -8.72 \\
\hline \multirow[t]{2}{*}{ Constant } & $80.03 * * *$ & -7.32 & $87.25 * * *$ & $54.91 * * *$ & $36.64 * * *$ & $18.27 * * *$ & $26.43 * * *$ & $11.90 * * *$ & $34.20 * * *$ \\
\hline & \multicolumn{9}{|c|}{ Endline II } \\
\hline Treatn & -0.63 & 1.93 & -2.56 & 1.31 & -0.45 & 1.77 & -0.06 & 0.63 & -0.88 \\
\hline Old Business & $8.78 * * *$ & $53.33 * * *$ & $-44.55 * * *$ & $7.33 * * *$ & $-14.20 * * *$ & $21.53 * * *$ & 0.30 & $-1.54 *$ & 1.27 \\
\hline Literacy $(\mathrm{HH})$ & -8.73 & -0.09 & -8.64 & -3.50 & 2.94 & -6.44 & $-10.32 * *$ & $-7.19 * *$ & $-9.94 *$ \\
\hline Constant & $89.11 * * *$ & $31.30 * * *$ & $57.80 * * *$ & $53.64 * * *$ & $28.25 * * *$ & $25.39 * * *$ & $26.07 * * *$ & $13.20 * * *$ & $29.55 * * *$ \\
\hline
\end{tabular}

$* 5 \%$ Level of Significance; ** 1\% Level of Significance; ***.01\% Level of Significance

Note: All coefficients are in Hours per Last 7 Days. SE Stands for Hours Worked in SelfEmployment. Out Stands for Hours Worked Outside

The social outcomes are given in Table 10, and it appears that there was no impact of increase in enrolment of either girls or boys in treatment areas. There is a slight marginal significant decline in 0.46 hours of work for boys in the age group of 5-15 at Endline II. There was a decline in women run businesses by a significant 0.04 times by Endline II. This shows very minor impact of micro-finance on promotion of women oriented businesses in the initial stages, but long run sustainability of businesses commenced is doubtful.

Table 11 and Table 12 shows the 30-day total monthly expenditure per household and 30-day per capita expenditure per household on different heads of expenditure respectively. There was a significant increase in expenditure on durable goods of INR. 96.47/- monthly and INR. 19.67/- monthly per capita, but a significant decline in expenditure on festivals of INR. 772.1/- monthly and INR. 14.04/- monthly per capita at Endline I in treatment areas. By Endline II, the incremental impact of 
treatment was no more significant. The coefficients of Old Business reported high significant coefficients at Endline I that were both lower and relatively insignificant by Endline II. Literacy on the other hand was associated with high positive significant coefficients for expenditure on non-durables, health and education but negative significant coefficients for expenditure on temptation items at Endline II. By Endline II, it appeared that the households had settled down to higher average levels of expenditure almost double that at Endline I though the percentage composition on different items of expenditure may have changed.

Table 10 Social Outcomes

\begin{tabular}{|c|c|c|c|c|c|c|c|}
\hline & \multicolumn{2}{|c|}{$\begin{array}{c}\text { School for 5-15 } \\
\text { Years }\end{array}$} & \multicolumn{2}{|c|}{$\begin{array}{c}\text { Hours worked in the Last } 7 \\
\text { days for Children 5-15 } \\
\text { Years }\end{array}$} & \multicolumn{2}{|c|}{$\begin{array}{c}\text { School for 16-20 } \\
\text { Years }\end{array}$} & \multirow{2}{*}{$\begin{array}{c}\text { Percentage o } \\
\text { Female- } \\
\text { Business }\end{array}$} \\
\hline & Girl & Boy & Girl & Boy & Girl & Boy & \\
\hline & \multicolumn{7}{|c|}{ Endline I } \\
\hline Treatment & -0.01 & -0.01 & -0.02 & 0.63 & -0.04 & -0.01 & -0.00 \\
\hline $\begin{array}{c}\text { Old } \\
\text { Business }\end{array}$ & -0.01 & 0.00 & -0.21 & 0.50 & 0.00 & -0.01 & $-0.08 * *$ \\
\hline $\begin{array}{c}\text { Literacy } \\
(\mathrm{HH})\end{array}$ & 0.03 & 0.04 & $-1.80 * * *$ & -3.90 & $0.27 * * *$ & $0.23 * *$ & 0.04 \\
\hline Constant & $0.88 * * *$ & $0.85 * * *$ & 0.43 & $4.82 * *$ & -0.01 & 0.13 & $0.36 * * *$ \\
\hline & \multicolumn{7}{|c|}{ Endline II } \\
\hline Treatment & 0.02 & 0.01 & 0.13 & $-0.46^{*}$ & 0.02 & -0.03 & $-0.04 *$ \\
\hline $\begin{array}{c}\text { Old } \\
\text { Business }\end{array}$ & 0.01 & -0.01 & -0.04 & 0.34 & -0.01 & 0.01 & -0.01 \\
\hline $\begin{array}{c}\text { Literacy } \\
(\mathrm{HH})\end{array}$ & $0.11 * * *$ & $0.09^{*}$ & -0.60 & -0.04 & $0.14 * *$ & $0.24 * * *$ & 0.02 \\
\hline Constant & $0.85 * * *$ & $0.81 * * *$ & 0.81 & $2.65 * * *$ & 0.12 & $0.23 * *$ & $0.30 * * *$ \\
\hline
\end{tabular}

$* 5 \%$ Level of Significance; $* * 1 \%$ Level of Significance; $* * * .01 \%$ Level of Significance

Table 11 Total Monthly Expenditure

\begin{tabular}{|c|c|c|c|c|c|c|c|c|}
\hline \begin{tabular}{|c} 
VARIABL \\
ES \\
\end{tabular} & Total & Durables & \begin{tabular}{|c|} 
Non- \\
Durables \\
\end{tabular} & Health & $\begin{array}{c}\text { Educatio } \\
\mathbf{n}\end{array}$ & Festival & $\begin{array}{c}\text { Temptatio } \\
\text { n }\end{array}$ & Food \\
\hline & \multicolumn{8}{|c|}{ Endline I } \\
\hline Treatment & 6.08 & $96.47 *$ & -78.13 & -8.67 & 0.24 & $-772.12 *$ & -37.86 & -68.35 \\
\hline $\begin{array}{l}\text { Old } \\
\text { Business }\end{array}$ & $1,275.2 * * *$ & $399.4 * * *$ & $887.93 * * *$ & 52.14 & $86.97 * *$ & $509.20 * *$ & $74.72 * * *$ & $236.69 * * *$ \\
\hline \begin{tabular}{|l} 
Total \\
Business
\end{tabular} & $-52.20 * * *$ & -6.37 & $-45.04 * * *$ & -4.41 & $-15.25 * * *$ & $-119.61 * * *$ & 0.17 & -9.44 \\
\hline $\begin{array}{l}\text { Literacy } \\
(\mathrm{HH})\end{array}$ & 211.27 & -100.15 & 274.99 & -206.66 & $346.28 *$ & $2,519.06$ & $-171.78 * *$ & 124.21 \\
\hline \multirow[t]{2}{*}{ Constant } & $2,872.7 * * * *$ & 175.56 & $2,684.3^{*} * *$ & 192.22 & -38.47 & $1,488.67$ & $426.84 * * *$ & $1,717.6^{* * * *}$ \\
\hline & \multicolumn{8}{|c|}{ Endline II } \\
\hline Treatment & -223.43 & 16.80 & -222.41 & -123.85 & 58.20 & 232.57 & -46.09 & -55.97 \\
\hline \begin{tabular}{|l|} 
Old \\
Business \\
\end{tabular} & $837.43 * * *$ & $85.64 * *$ & $724.92 * * *$ & 34.32 & $114.94 * *$ & $805.82 * * *$ & $61.58 * *$ & $367.46^{* * * *}$ \\
\hline \begin{tabular}{|l} 
Total \\
Business
\end{tabular} & $-47.63 * *$ & -6.21 & $-40.44 * *$ & $-14.65 * *$ & -5.63 & $-57.62 * * *$ & -3.69 & -3.88 \\
\hline $\begin{array}{l}\text { Literacy } \\
(\mathrm{HH})\end{array}$ & $1,513.90 * *$ & 64.59 & $1,463.67 * *$ & $801.2^{* * * *}$ & $477.43 * *$ & $1,172.26$ & $-350.58 * * *$ & 371.14 \\
\hline Constant & $6,090.18$ **** & $520.5 * * *$ & $5,536.4 * * *$ & $511.44 * *$ & 258.51 & $3,160.8^{* * *}$ & $748.47 * * *$ & $3,401.2 * * *$ \\
\hline
\end{tabular}


Table 12 Per Capita Monthly Expenditure

\begin{tabular}{|l|c|c|c|c|c|c|c|c|}
\hline $\begin{array}{c}\text { VARIABLE } \\
\text { S }\end{array}$ & Total & $\begin{array}{c}\text { Durable } \\
\mathbf{s}\end{array}$ & $\begin{array}{c}\text { Non- } \\
\text { durables }\end{array}$ & Health & $\begin{array}{c}\text { Educatio } \\
\mathbf{n}\end{array}$ & Festival & $\begin{array}{c}\text { Temptatio } \\
\mathbf{n}\end{array}$ & Food \\
\hline & \multicolumn{8}{|c|}{ Endline I } \\
\hline Treatment & 7.79 & $19.67^{*}$ & -9.14 & -3.95 & -1.12 & $-14.04^{*}$ & $-8.78^{*}$ & -12.89 \\
\hline Old Business & $149.5^{* * *}$ & $70.32^{* * *}$ & $81.70^{* * *}$ & -1.24 & 12.34 & 3.43 & $8.88^{* *}$ & 4.59 \\
\hline $\begin{array}{l}\text { Literacy } \\
\text { (HH) }\end{array}$ & 101.81 & -1.58 & 98.22 & -45.23 & $78.91^{* *}$ & $49.62^{*}$ & $-30.89^{*}$ & 36.93 \\
\hline Constant & $775.9^{* * *}$ & 38.93 & $735.8^{* * *}$ & 64.94 & 5.34 & 32.78 & $105.76^{* * * *}$ & $438.9^{* * *}$ \\
\hline \multicolumn{8}{|c|}{ Endline II } \\
\hline Treatment & -45.25 & 2.21 & -43.61 & -22.62 & 9.59 & 6.40 & -8.76 & -14.68 \\
\hline Old Business & $74.02^{* *}$ & $16.36^{*}$ & 51.85 & 0.28 & 12.19 & 6.24 & 4.75 & 23.94 \\
\hline $\begin{array}{l}\text { Literacy } \\
\text { HH) }\end{array}$ & $283.49^{*}$ & 10.78 & $272.34^{*}$ & $164.7^{* * *}$ & $102.29^{*}$ & 18.24 & $-82.26^{* * *}$ & 60.09 \\
\hline Constant & $1,520.2^{* * *}$ & $125.0^{* * *}$ & $1,384.5^{* * *}$ & $139.03^{* *}$ & 74.97 & $61.7 * * *$ & $184.36^{* * *}$ & $824.4^{* * *}$ \\
\hline
\end{tabular}

$* 5 \%$ Level of Significance; ** 1\% Level of Significance; ***.01\% Level of Significance

\section{Conclusions}

A comparison of outcomes of intervention by Spandana shows some impact in treatment groups at Endline I as compared to control groups. By the end of Endline II when Spandana started lending in control group areas, the difference across control and treatment groups more or less petered out, although total indebtedness had considerably increased. The number of total businesses might have increased, but there was no further incremental impact through microfinance interventions after Endline I. The results across most outcomes indicates that the impact of microfinance may have some significance at early stages, but in the long run, impacts appear doubtful. Further, those with existing businesses might have tended to benefit more from microfinance interventions compared to new entrants. From a policy perspective, it appears that simple rollouts of microfinance interventions may not completely substantially reduce the borrowing from informal sources, though it may tend to supplant bank financing. The low increase in entrepreneurship is also a reflection that microfinance intervention without skill training may not succeed.

Lastly, business models of microfinance may need to be tweaked to have higher positive social outcomes. The original concept of a microfinance or microcredit was intended as a social intervention tool to address poverty. It was therefore characterized by small transactions, collateral free loans for entrepreneurial activity, group lending, targeting of poor clients in underserved communities especially female clients, simple application processes and market-level interest rates (Karlan and Goldberg 2007). Though microfinance organizations were projected to be sustainable, they were never ever considered as for profit institutions. Policy makers are thus stuck in a conundrum expecting that a for-profit model would results in social transformation. The most important question therefore that needs to be answered is, can mere access of funds without an accompanying supporting infrastructure, resolve social dynamics and pull out households from the cycle of poverty and lack of opportunities. The results from the evaluation of the microfinance intervention do not support that assumption. Indeed, the failure of the Spandana model and in some ways the failure of the industry stems from the divergence of microfinance from its essential characteristics (Stiglitiz and Haldar 2013). There was a breakdown of the social capital and the peer monitoring 
mechanism in the wake of huge overlapping across multiple providers with no loyalty to any one provider. The providers were purely commercial institutions with no intention to invest in any kind of training and handholding of households. Secondly, the mass scaling up and rapid proliferation that was adopted by the organization may not be entirely suitable to the microfinance industry which is essentially meant to build on customized requirements of its stakeholders. It also gave no room for any kind of learning or mid-course correction to make any kind of adaptations to the social and cultural milieu of borrowers. In fact, the shift to a profit for model led to exploitative practices and a further disintegration of relationship between the client and the provider.

Changes in the regulatory framework has no doubt brought in more checks and balances within the system preventing it from employing unfair practices or exploitative mechanisms while also regulating extent of indebtedness. This has reduced operational margins forcing the industry to concentrate on urban areas where entrepreneurship avenues may not be very attractive as evident from the Spandana experience. The full impact of this transition on the fortunes of the microfinance industry in India may only be known after a gap of another 3-5 years. The social and livelihood enhancement impact on borrowers too, would also need to be rigorously evaluated to arrive at some generalizable conclusions. Nevertheless, results of this evaluation, broadly similar to evaluations done in other countries, do seem to indicate that "microfinance is not for every household, or even most households, and it does not lead to the miraculous social transformation some proponents have claimed (Banerjee, Karlan and Zinman 2015).

\section{References}

1. Bandhyopadhyay, Tamal, and Dinesh UnniKrishnan. "India's oldest microfinance firm on the verge of closure." LiveMint. July 27, 2011. http://www.livemint.com/Home-

Page/jQEWbu91AAN9xT34uIadEN/India8217s-oldest-microfinance-firmon-the-verge-of-closu.html (accessed August 23, 2016).

2. Bandyopadhyay, Tamal. "Indian microfinance institutions have just busted a myth." Livemint. October 2015. http://www.livemint.com/Opinion/vKWsSxGepyqdNP4hNTrw7H/Indianmicrofinance-institutions-have-just-busted-a-myth.html (accessed August 23, 2016).

3. Banerjee, Abhijit, Dean Karlan, and Jonathan Zinman. "American Economic Journal: Applied Economics." Six Randomized Evaluations of Microcredit: Introduction and Further Steps 7, no. 1 (2015): 1-21.

4. Banerjee, Abhijit, Esther Duflo, Rachel Glennerster, and Cynthia Kinnan. "The Miracle of Microfinance? Evidence from a Randomized Evaluation." American Economic Journal: Applied Economics 7, no. 1 (2015): 22-53.

5. Bannerjee, Abhijit, Dean Karlan, and Jonathan Zinman. "Six Randomized Evaluations of Microcredit: Introduction and Further Steps." American Economic Journal: Applied Economics 7, no. 1 (2015): 1-21.

6. Bannerjee, Abhijit, Esther Duflo, Cynthia Kinnan, and Rachel Glennerster. "The Miracle of Microfinance." Working Paper, May 2009: 40.

7. Bauchet, Jonathan, Cristobal Marshall, Laura Starita, Jeanette Thomas, and Anna Yalouris. "Latest Findings of Randomized Evaluations of 
Microfinance." Access to Finance Forum: Reports by CGAP and its partners, no. No 2 (December 2011).

8. Biswas, Soutik. "India's micro-finance suicide epidemic." BBC News. December 16, 2010. http://www.bbc.com/news/world-south-asia-11997571 (accessed August 23, 2016).

9. CGAP. "Andhra Pradesh 2010: Global Implications of the Crisis in Indian Microfinance." CGAP Website. November 2010. http://www.cgap.org/sites/default/files/CGAP-Focus-Note-Andhra-Pradesh2010-Global-Implications-of-the-Crisis-in-Indian-Microfinance-Nov2010.pdf (accessed August 26, 2016).

10. Chandrakumarmangalam, S., and S.C. Vetrivel. "Impact of Group-Based Microfinance on Rural Households in India." The IUP Journal of Management Researc XI, no. 2 (2012): 78-89.

11. Chen, Greg, Stephen Rasmussen, Xavier Reille, and Daniel Rozas. "Indian Microfinance Goes Public: The SKS Initial Public Offering." CGAP Website. September 2010. https://www.cgap.org/sites/default/files/CGAPFocus-Note-Indian-Microfinance-Goes-Public-The-SKS-Initial-PublicOffering-Sep-2010.pdf (accessed August 26, 2016).

12. Crepon, Bruno, Florencia Devoto, Esther Duflo, and William Pariente. "Estimating the Impact of Microcredit on Those Who Take It Up: Evidence from a Randomized Experiment in Morocco." American Economic Journal: Applied Economics 7, no. 1 (2015): 123-150.

13. Duvendack, Maren, and Richard Palmer-Jones. "High Noon for Microfinance Impact Evaluations: Re-investigating the Evidence from Bangladesh." Journal of Development Studies 48, no. 12 (December 2012): 1864-1880.

14. Ernst and Young. "Evolving Landscape of Microfinance Insitutions in India." Ernst and Young Website. July 2016. http://www.ey.com/Publication/vwLUAssets/ey-evolving-landscape-ofmicrofinance-institutions-in-india/\$FILE/ey-evolving-landscape-ofmicrofinance-institutions-in-india.pdf (accessed August 27, 2016).

15. Ghiyazuddin, and Shruti Gupta. Andhra Pradesh MFI Crisis and its impact on clients. Sector Report, Hyderabad: IFMR-Centre for Microfinance and Microsave, 2012.

16. Johnson, Doug, and Sushmita Meka. Access to Finance in Andhra Pradesh. Survey Report, Hyderabad: Institute for Financial Management and Research, 2010.

17. Karlan, Dean, and Nathanael Goldberg. Impact Evaluation for Microfinance: Review of Methodological Issues. Report, Poverty Reduction and Economic Management, World Bank, Washington: World Bank, 2007.

18. Khandker, Shahidur R. "Microfinance and Poverty: Evidence using Panel Data from Bangladesh." World Bank Economic Review 19, no. 2 (2005): 263-286.

19. Mader, Phillip. "Rise and Fall of Microfinance in India: The Andhra Pradesh Crisis in Perspective." Strategic Change 22, no. 1-2 (2013): 47-66.

20. Mahajan, Vijay, and T. Navin. "Microfinance in India: Lessons from the Andhra Crisis." Microfinance Institutions Network. 2012. http://mfinindia.org/wp- 
content/uploads/2014/06/andhra_crisis_10022014.pdf (accessed August 23, 2016).

21. Malegam, Y.H. Report of the Sub-Committee of the Central Board of Directors of of Reserve Bank of India to Study Issues and Concerns in the MFI Sector. Committee Report, New Delhi: Reserve Bank of India, 2011.

22. MFIN. "Micrometer." MFIN Website. May 31, 2016. http://mfinindia.org/wp-content/uploads/2016/05/Micrometer-Issue-17Q4\%20FY-15-16-19th-May-2016-public.pdf (accessed August 27, 2016).

23. MIX Market. "MIX Microfinance World: How has the growth of Indian microfinance been funded." MIX Market. December 1, 2010. https://www.themix.org/sites/default/files/publications/MMW-

$\% 20$ how $\% 20$ has $\% 20$ the $\% 20$ growth $\% 20$ of $\% 20$ indian $\% 20$ microfinance $\% 20$ been\%20funded-\%20print\%20ready_0.pdf (accessed August 23, 2016).

24. Moneycontrol.com. Spandana Microfinance plans to raise Rs $1500 \mathrm{cr}$ via IPO. August 20, 2010. http://www.moneycontrol.com/news/ipo-upcomingissues/spandana-microfinance-plans-to-raise-rs-1500cr-viaipo_479864.html (accessed September 1, 2016).

25. Orazio , Attanasio, Britta Augsburg, Ralph De Haas, Emla Fitzsimons, and Heike Harmgart. "The Impacts of Microfinance: Evidence from JointLiability Lending in Mongolia." American Economic Journal: Applied Economics 7, no. 1 (2015): 90-122.

26. PTI. "Microfinance industry back on growth path." Economic Times. September 9,

2015. http://economictimes.indiatimes.com/industry/banking/finance/microfinanc e-industry-back-on-growth-path-report/articleshow/48890424.cms (accessed August 27, 2016).

27. Srinivasan, N. Microfinance India: State of the Sector Report 2010. Access Development Services Yearly Report, New Delhi: Sage Publications India Pvt. Ltd, 2010.

28. Srivastava, Pradeep, and Priya Basu. "Scaling-up Access to Finance for India's rural poor." World Bank. May 23, 2004. http://info.worldbank.org/etools/docs/reducingpoverty/case/111/fullcase/Ind ia\%20Microfinance\%20Rural\%20Full\%20Case.pdf (accessed August 2016).

29. State Government of Andhra Pradesh. " G.O.M.S. 356, Panchayat Raj \& Rural Development (RD-1)." October 19, 2010.

30. Stiglitiz, Joseph E., and Antara Haldar. "The Indian Microfinance Crisis: The Role of Social Capital, the Shift to for Profit-lending and Implications for Microfinance Theory and Practice." Working Paper, Columbia University, 2013.

\section{About Our Author}

Dr. Vinti Agarwal is currently working as Sr. Research Manager in BBC Media Action, India. BBC Media Action is the international development charity arm of British Broadcasting Corporation, United Kingdom. She is handling quantitative research and impact evaluation for media and communications interventions in the areas of public health, sanitation and social and gender empowerment. She has held 
previous academic positions at National Institute of Financial Management, ICFAI Business School, Nirma Institute of Management and non-academic positions at Indore Cancer Foundation. Her academic experience has spanned research, teaching, consulting and capacity development. Her academic training has been in Economics, Finance, Research Methods and Data Analytics with academic institutions of Ch. Charan Singh University, Institute of Chartered Financial Analysts of India and Johns Hopkins University respectively. 